\title{
Genetic population structure of mangrove jack, Lutjanus argentimaculatus (Forsskål)
}

\author{
Jennifer R. Ovenden ${ }^{\mathrm{A}, \mathrm{B}}$ and Raewyn Street ${ }^{\mathrm{A}}$ \\ ${ }^{\text {A } M o l e c u l a r ~ F i s h e r i e s ~ L a b o r a t o r y, ~ S o u t h e r n ~ F i s h e r i e s ~ C e n t r e, ~ A g e n c y ~ f o r ~}$ \\ Food and Fibre Sciences (Fisheries), Queensland Department of Primary Industries, \\ PO Box 76, Deception Bay, Qld 4508, Australia. \\ ${ }^{\mathrm{B}}$ Corresponding author; email: jennifer.ovenden@dpi.qld.gov.au
}

\begin{abstract}
Translocations of mangrove jack, Lutjanus argentimaculatus (Forsskål 1775), to increase angling opportunities in artificial impoundments are foreshadowed in Queensland. To evaluate genetic population structure before translocations occur, mangrove jack were collected from three sites on the Queensland coast and from one site on the north-western coast of Western Australia. Allelic variation at four dinucleotide microsatellite loci was high: gene diversity (heterozygosity) ranged from 0.602 to 0.930 and allelic counts from 10 to 24 . Genetic differentiation among collection sites was weak: estimates of $F_{\mathrm{ST}}$ were 0.002 for all four sites, and less $\left(F_{\mathrm{ST}}=0.001\right)$ across a major biogeographical boundary (the Torres Strait region). Nucleotide sequence from two mitochondrial regions (control, 375 base pairs, and ATPase, 415 base pairs) was obtained from a subset of the Australian and additional Indo-Pacific (Indonesian and Samoan) mangrove jack. Haplotype diversity was high (control region, 33 haplotypes for 34 fish; ATPase region, 13 haplotypes for 56 fish). Phylogenetic analysis of mitochondrial DNA sequence data could not discern a relationship between tree topology and geography. These results suggest that mangrove jack in Queensland, and possibly throughout Australia, experience high levels of gene flow. The artificial gene flow caused by permitted translocations is unlikely to exceed natural levels. Fine-scale ecological matching between donor and recipient populations may increase stocking success, and is important if translocation is needed as a species recovery tool in the future.
\end{abstract}

Extra keywords: adaptive divergence, evolutionarily significant unit, Lutjanus, microsatellite, mitochondrial DNA, translocation.

\section{Introduction}

The beneficial role that population genetics analyses of fisheries species can play in their sustainable management is widely known (Shaklee 1983; Ovenden 1990; Ward and Grewe 1994). The key benefits include: (l) direct statistical testing of the null hypothesis of a single panmictic population; (2) wide applicability across species; (3) use of naturally occurring genetic variation, which eliminates the costs and assumptions of artificial tagging; and (4) avoidance of the effects of environmental conditions, which are known to influence meristic and morphometric characters (Shaklee and Bentzen 1998).

For commercial marine species such as finfish, crustaceans and molluscs, genetic information on the degree of population subdivision in space and time is important to the design of management regimes. For example, the application of uniform catch quotas across an assemblage of genetically separate populations may result in local extinction, especially in hyperstable species where catch per unit effort does not decline at the same rate as biomass. For commercial estuarine and freshwater species, where the presence of population subdivision is likely to be more common and pronounced, there is an additional management consideration. Genetically distinct populations may be brought into contact and mixed, intentionally or accidentally, when a species is translocated for captive breeding, fisheries enhancement or other purposes (Skibinksi 1997). Although it has been argued that intraspecific hybridization may not be harmful (Keenan 1998), loss of local adaptations may occur when interbreeding disrupts genetically linked gene complexes and consequently reduces fitness. These complexes may confer advantages during periods of stress associated with environmental change or onset of disease (Allendorf et al. 2001). Government fisheries-protection agencies often have policies to protect endemic aquatic species against these and other detrimental effects of translocation (Anon. 1999).

Mangrove jack, Lutjanus argentimaculatus (Forsskål 1775), is a member of the most common genus in the snapper family (Lutjanidae). In a predominantly tropical marine IndoPacific group, it is the only Australian species of this group 
to enter fresh water where juveniles and subadults are common. Adults are found in marine habitats such as reefs $100 \mathrm{~m}$ deep, where they may reach $16 \mathrm{~kg}$. Mangrove jack are distributed in northern and eastern Australia from Ningaloo Reef in Western Australia to Sydney in New South Wales, and they are widespread in the Indo-Pacific from East Africa to Samoa and north to Japan (Allen et al. 2002). A small commercial fishery operates in Queensland and north-west Western Australia, where reef-dwelling individuals are taken by line and trap. The species has also been domesticated, and captive breeding occurs in South-East Asia and Australia (Doi and Singhagraiwan 1993; Garrett 1994). It is prized by anglers for its aggressiveness and has good table characteristics. In Queensland, selected inland freshwater impoundments may be stocked with captive-bred mangrove jack to promote recreational fishing opportunities.

A comprehensive set of precedents exists for genetic population subdivision in marine and estuarine fish, and Shaklee and Bentzen (1998) have identified categories representing varying gradations of genetic subdivision. Some marine species are highly subdivided over small distances, for example catfish (Cnidoglanis macrocephalus) (Ayvazian et al. 1994) and damselfish (Acanthochromis polyacanthus) (Doherty and Fowler 1994). Both lack a pelagic larval stage and have limited gene flow between adjacent populations. Mangrove jack has a pelagic larval stage, but its vagility and duration are unknown. In contrast, other marine species are subdivided over larger distances. Australian inshore marine species such as barramundi (Lates calcarifer) (Keenan 1994) and school mackerel (Scomberomorus queenslandicus) (Begg et al. 1998) that spawn in estuaries (barramundi) or coastal embayments (mackerel) along the Queensland coastline conform to this pattern. Mangrove jack spawn 40-50 km offshore and can disperse up to several hundred kilometres on maturity (J. Russell, personal communication). Shaklee and Bentzen (1998) also distinguish species that appear genetically homogeneous over a large range but are subdivided in one or more areas. An excellent example is Western Australian pink snapper [Pagrus (Chrysophrys) auratus], which was genetically homogeneous over $4500 \mathrm{~km}$ of its Australian distribution, yet subdivided within Shark Bay, Western Australia (Johnson et al. 1986). Shared biogeographic features can also be an important factor. In Australia, the genetic division of populations of numerous species to the east and west of the shallow waters of Torres Strait, such as the green turtle (Chelonia mydas) (Fitzsimmons et al. 1997) and barramundi (Chenoweth et al. 1998a), may be explained by pre-Pleistocene fluctuations in sea level that periodically interrupted the marine pathway between the Indian and Pacific oceans. The distribution of mangrove jack in Australia straddles the Torres Strait region, and if their vagility were similar to barramundi or Spanish mackerel (Scomberomorus commerson), then genetic subdivision would be expected to the east and west of Cape York.
The purpose of this study was to assess the degree of population subdivision in mangrove jack throughout its Australian distribution, particularly in Queensland. Its biphasic life history, in which juveniles and subadults live in estuaries and fresh water and adults live in the sea, suggests that the scale of dispersal may be limited and the species may be genetically subdivided. Alternatively, dispersal may be extensive during the adult or larval phases, leading to genetic homogeneity. Distinction between these hypotheses is important for the licensing of the species for aquaculture and impoundment stocking in Australia under regulations that limit translocations between areas occupied by genetically distinct populations. Two classes of genetic markers were used: nuclear (microsatellite) and mitochondrial loci. Both confer the advantage of sampling fish non-lethally and provide a powerful test of genetic homogeneity (Buonaccorsi et al. 2001). In addition, mitochondrial sequence data can provide insights into the evolutionary history of populations under certain circumstances.

\section{Materials and methods}

Sampling

\section{Microsatellites}

Mangrove jack were genotyped from four locations in Australia:

(1) south-east Queensland (SQ; Gladstone to the Gold Coast, about $\left.24-28^{\circ} \mathrm{S} 151-153^{\circ} \mathrm{E}\right)$

(2) north Queensland (NQ; between Cape Melville and Hinchinbrook Island, about $\left.14-18^{\circ} \mathrm{S} 145-146^{\circ} \mathrm{E}\right)$;

(3) the Gulf of Carpentaria (GOC; north and south of Weipa, about $11-14^{\circ} 30^{\prime} \mathrm{S} 141-142^{\circ} \mathrm{E}$, and the southern Gulf, about $16^{\circ} 30^{\prime} \mathrm{S}$ $\left.138^{\circ} \mathrm{E}\right)$; and

(4) Western Australia (WA, west Sahul Banks, about $13-14^{\circ} \mathrm{S} 123$ $124^{\circ} \mathrm{E}$, and Port Headland to Dampier, about $\left.20^{\circ} \mathrm{S} 116-119^{\circ} \mathrm{E}\right)$ (Fig. 1).

Fish were sampled from estuaries and freshwater rivers (GOC) and offshore reefs (WA, 11 from reefs and 92 from rivers; NQ, 35 from reefs and 66 from rivers; and SQ, 3 from reefs and 61 from rivers). They were taken from research, recreational and commercial catches during 1999, 2000 and 2001

About $10-20 \mathrm{~mm}^{2}$ of fin tissue was removed non-lethally, where possible, and stored in DMSO (20\% dimethyl sulphoxide in $5 \mathrm{M}$ sodium chloride) at room temperature in the field and $-80^{\circ} \mathrm{C}$ in the laboratory.

A target of 100 fish from each location was set for genotyping. Binomial theory describes the probability of collecting an allele of frequency $p$ as:

$$
n=[\ln (1-\alpha) / \ln (1-p)] / 2
$$

where $n$ is the number of individuals required and $\alpha$ is the confidence level desired (Bartley et al. 1995). For example, a minimum of 74 fish is needed to capture a rare allele of frequency 0.02 at a $95 \%$ confidence level.

\section{Mitochondrial DNA}

Mangrove jack analysed for mitochondrial DNA (mtDNA) were a subset of those genotyped with microsatellites, with the addition of samples from four sampling locations outside Australian waters in the 


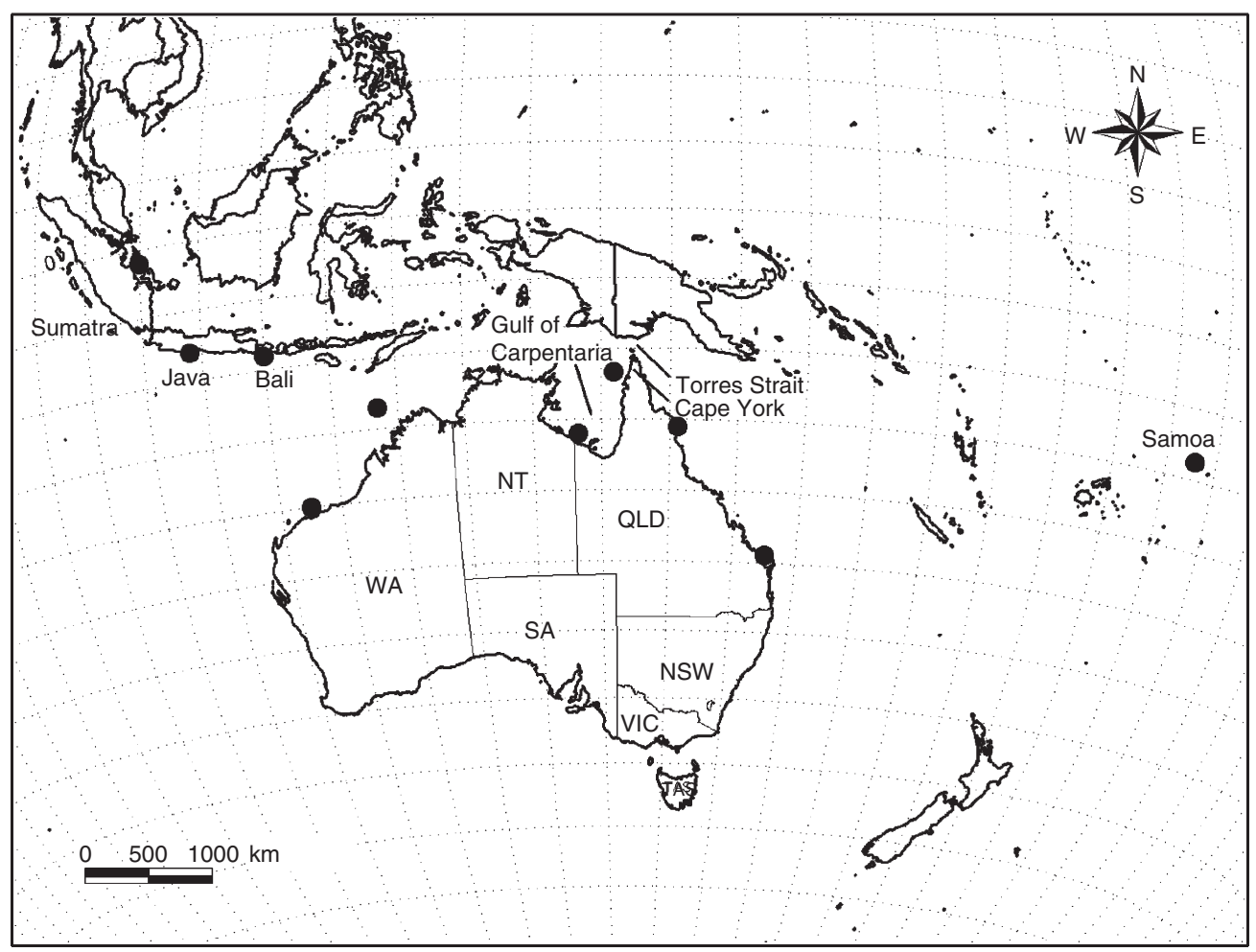

Fig. 1. Collection locations of mangrove jack populations in Australia (southern and northern Queensland, Gulf of Carpentaria, Western Australia), Indonesia (Bali, Java, Sumatra) and Western Samoa.

Table 1. Numbers of mangrove jack from Australia (SQ, NQ, GOC, WA) and the Indo-Pacific (Bali, Java, Sumatra and Samoa) from which mtDNA nucleotide sequence data was obtained

mtDNA sequence data was collected from the control region (CR) and the ATPase genes

\begin{tabular}{lcc}
\hline Sampling location & \multicolumn{2}{c}{$\begin{array}{c}\text { No. of fish } \\
\text { ATPase gene }\end{array}$} \\
\hline SQ & 5 & 10 \\
NQ & 6 & 11 \\
GOC & 5 & 9 \\
WA & 5 & 10 \\
Bali & 5 & 5 \\
Java & 2 & 4 \\
Sumatra & 3 & 4 \\
Samoa & 3 & 3 \\
Total & 34 & 56 \\
\hline
\end{tabular}

Indo-Pacific (Table 1). The Indo-Pacific sampling locations were in Indonesia from the islands of Bali $\left(9^{\circ} \mathrm{S} 115^{\circ} \mathrm{E}\right)$, Java $\left(8^{\circ} \mathrm{S} 109^{\circ} \mathrm{E}\right)$ and Sumatra $\left(1^{\circ} \mathrm{S} 105^{\circ} \mathrm{E}\right)$, and in Western Samoa $\left(13^{\circ} \mathrm{S} 172^{\circ} \mathrm{E}\right)$ (Fig. 1).

\section{Laboratory protocol}

\section{DNA isolation}

Genomic DNA was isolated from 10 to $25 \mathrm{mg}$ of preserved fin tissue with commercial kits [Qiagen (Melbourne) DNeasy tissue kit or BioRad (Sydney) Aquapure genomic tissue kit].

\section{Microsatellites}

Some 44 microsatellite loci developed for coral trout (Plectropomus laevis) and red-throat emperor (Lethrinus miniatus) were evaluated as population genetic markers for mangrove jack (van Herwerden et al. $2000 a$ ). Four suitable loci were found and these were used in this study (Table 2).

Microsatellite amplification, gel separation and scoring were performed by the AGRF (Australian Genome Research Facility, Walter and Eliza Hall Institute, Melbourne). Polymerase chain reactions (PCRs) $(20 \mu \mathrm{l})$ consisted of up to $1 \mu \mathrm{g}$ of template DNA, $200 \mu \mathrm{M}$ of each dNTP, $0.1-0.5 \mu \mathrm{M}$ of each primer and $2.5 \mathrm{U}$ of Taq polymerase. Cycling conditions were $30 \mathrm{~s}$ at $94^{\circ} \mathrm{C}, 30 \mathrm{~s}$ at the recommended annealing temperature and $1 \mathrm{~min}$ at $72^{\circ} \mathrm{C}$.

\section{Mitochondrial DNA}

About 375 base pairs (bp) of the $5^{\prime}$ end of the control region (D-loop) was amplified as described (Ovenden et al. 2002), but using primers Pro889U20 (CCW CTA ACT CCC AAA GCT AG) and TDKD1291L21 (CCT GAA ATA GGA ACC AAA TGC).

Primers COIII.2 [GTT AGT GGT CA(GT) GGG CTT GG(AG); supplied by E. Bermingham, Smithsonian Tropical Research Institute] and MJB1567U22 (CCT TAA CAT GCT CGC ACT ACT C) were used to amplify about $400 \mathrm{bp}$ of the protein-coding ATPase 6 gene. This region was chosen because it spanned a cluster of single-nucleotide polymorphisms revealed by a comparison of the sequence of several mangrove jack from the entire ATPase 6 and 8 genes.

Forward and reverse PCR primers for the control region and the ATPase 6 region were used to sequence purified PCR products. Sequences were obtained with an $\mathrm{ABI}$ automated sequencer by the chain-termination method with Big Dye terminators. Sequence data was aligned with Sequencher version 3.12 (Anon. 2000). 
Table 2. Characteristics of microsatellite markers in coral trout and red-throat emperor developed by van Herwerden et al. (2000a)

These loci were used for mangrove jack in this study. F, forward; R, reverse

\begin{tabular}{|c|c|c|c|c|}
\hline Locus & Species & Repeat motif & Primers $\left(5^{\prime}\right.$ to $\left.3^{\prime}\right)$ & Genbank no \\
\hline BST2.33 & Coral trout & $(\mathrm{TG})_{35}(\mathrm{CG})_{12}$ & $\begin{array}{l}\text { F TAATGCCCACAAACCTGCTGG } \\
\text { R ATGTTCCACAACGCCTGACAAACC }\end{array}$ & AF249850 \\
\hline BST6.39TG & Coral trout & $(\mathrm{TG})_{17}$ & $\begin{array}{l}\text { F GCAGCATTAAGTGAGAGAGGC } \\
\text { R GGATAATGTAGGGCCAGAGCG }\end{array}$ & AF249855 \\
\hline BST6.56 & Coral trout & $(\mathrm{TG})_{8}$ & $\begin{array}{l}\text { F ACGTGAGCATTCAGGGTAA } \\
\text { R ATCTCCATCATCTGCTGCCTTGG }\end{array}$ & AF249857 \\
\hline 90RTE & Red-throat emperor & $(\mathrm{TG})_{17}$ TATGAG(TG) 4 & $\begin{array}{l}\text { F ATGCTGTCCACTTCCTCCAGC } \\
\text { R TTTCTCAAACTCCTGCCCTTCC }\end{array}$ & AF261002 \\
\hline
\end{tabular}

\section{Analysis methods}

\section{Microsatellites}

Allele frequency estimation, linkage disequilibrium, heterozygosity and Hardy-Weinberg tests were calculated from raw data with Genepop on the Web (Morgan 2000), which is based on Genepop version 3.3 (Raymond and Rousset 1995) (dememorization 5000, batches 500 , iterations per batch 1000). Linkage disequilibrium was tested by goodness-of-fit procedures with the null hypothesis that genotypes at one locus were independent of genotypes at the other locus. Observed heterozygosity, the proportion of individuals in the sample that were observed to be heterozygous by direct counting, was calculated for each locus and for each population. Exact tests for conformance to Hardy-Weinberg proportions were performed by the complete enumeration method for each microsatellite locus and each population sample.

Several low-frequency alleles for locus BST6.39TG were pooled so that their pooled frequencies summed across population samples was greater than 0.025 . At this frequency, there would have been a greater than $95 \%$ chance of detecting them in 62 or more fish; the SQ population sample consisted of 62 fish. Pooled allele frequencies were used in subsequent tests for population subdivision.

The significance of differences in allele frequencies between populations was tested with an analogue of Fisher's exact test, the log-likelihood $G$-test, by Genepop on the Web (dememorization 5000, batches 500, iterations per batch 1000). Analysis of molecular variance (AMOVA; Excoffier et al. 1992) was used to assess the significance of differing geographical groupings by quantifying the inter- and intragroup component of total variance using analogues of $F$-statistics in Arlequin version 2.0 (Schneider et al. 2000). Statistical significance was inferred from a null distribution constructed from a random allocation of genotypes to simulated populations that have the same sample sizes as the original populations.

\section{Mitochondrial DNA}

The 'filter taxa' utility of MacClade (Maddison and Maddison 1992) was used to determine the number of haplotypes from sequence data from the control region and ATPase 6 regions. The molecular distance among sequences was calculated according to the Kimura two-parameter method (Kimura 1980) with mutation rates for variable sites assumed to follow the gamma distribution with shape 0.5 (Yang 1996).

Maximum parsimony trees (MPTs) were constructed from sequence data with the heuristic search option of PAUP* version 4.0b10 (Swofford 1999). Indels were regarded as 'fifth' bases. Characters were not weighted. The strict consensus method was used to summarize MPTs where appropriate.

\section{Results}

\section{Microsatellites}

The number of fish genotyped from each population sample was 61-63 across loci for SQ, 88-102 for NQ, 87-93 for GOC and 90-102 for WA. Locus BST6.39TG had the most missing data: $5-10 \%$ of samples could not be reliably genotyped. The number of alleles per locus was 10 for 90RTE and BST6.56, 9 for BST2.33, and 24 for BST6.39TG after pooling selected low-frequency alleles (Table 3). Locus BST6.39TG had the highest level of heterozygosity (proportion of total number of expected heterozygotes, 0.930 ). Loci 90RTE, BST6.56 and BST2.33 had lower levels of heterozygosity $(0.786,0.602$ and 0.636 , respectively).

Linkage disequilibrium may have been possible for one pair of loci (90RTE, BST2.33) in one population (WA). This comparison returned a $P$-value $(0.0001)$ that was significant after Bonferroni adjustment (Rice 1989). No pattern of genotype association for these loci was observable in the WA sample, and this pair of loci was not in linkage disequilibrium in the remaining three population samples. This suggested that it was unlikely that the two loci were physically linked in the genome. It was therefore concluded that there was no significant association among genotypes at the four microsatellite loci.

Observed and expected genotypic proportions for microsatellite loci were in general agreement with the HardyWeinberg principle. For locus BST2.33, two population samples had significantly different proportions of observed and expected heterozygotes and homozygotes (NQ, $P=$ 0.0076 ; GOC, $P=0.0219$ ). In these populations the numbers of observed homozygotes $(48,48)$ were above that expected $(41,34)$ and the numbers of observed heterozygotes $(53,43)$ were lower than expected $(59,57)$. Locus BST6.39TG showed a similar pattern in the SQ and WA populations. However, none of the $P$-values across all four loci was significant for the population samples and it was concluded that the genotypes conformed to Hardy-Weinberg proportions. Excess homozygosity (heterozygote deficit) is often observed when microsatellite markers are used on wild 
Table 3. Allelic frequencies for four microsatellite loci for mangrove jack from SQ, NQ, GOC and WA For locus BST6.39TG, four alleles $(666,777,888$ and 999) are pooled low-frequency alleles. $n$, numbers of fish sampled

\begin{tabular}{|c|c|c|c|c|c|c|c|c|c|c|c|}
\hline \multicolumn{5}{|l|}{ Population } & \multicolumn{6}{|c|}{ Allele frequency } & \multirow[t]{2}{*}{$2 n$} \\
\hline & & & & & & & & & & & \\
\hline Allele no. & 1 & 2 & 3 & 4 & 5 & 6 & 7 & 8 & 9 & & \\
\hline Allele size (bp) & 175 & 183 & 185 & 189 & 191 & 193 & 195 & 197 & 199 & & \\
\hline SQ & 0 & 0 & 0 & 0.048 & 0.246 & 0.230 & 0.206 & 0.183 & 0.087 & & 126 \\
\hline NQ & 0 & 0.005 & 0 & 0.044 & 0.255 & 0.304 & 0.157 & 0.181 & 0.054 & & 204 \\
\hline GOC & 0.005 & 0.005 & 0 & 0.032 & 0.204 & 0.242 & 0.210 & 0.247 & 0.054 & & 186 \\
\hline WA & 0 & 0 & 0.005 & 0.025 & 0.211 & 0.265 & 0.176 & 0.294 & 0.025 & & 204 \\
\hline \multicolumn{12}{|l|}{ Locus BST6.56 } \\
\hline Allele no. & 1 & 2 & 3 & 4 & 5 & 6 & 7 & 8 & 9 & 10 & \\
\hline Allele size (bp) & 129 & 131 & 133 & 135 & 137 & 139 & 145 & 147 & 149 & 151 & \\
\hline SQ & 0.008 & 0.484 & 0.008 & 0 & 0.379 & 0.073 & 0.032 & 0.008 & 0 & 0.008 & 124 \\
\hline NQ & 0 & 0.469 & 0.010 & 0 & 0.428 & 0.067 & 0.021 & 0 & 0.005 & 0 & 194 \\
\hline GOC & 0 & 0.378 & 0.006 & 0.011 & 0.511 & 0.056 & 0.028 & 0.006 & 0.006 & 0 & 180 \\
\hline WA & 0 & 0.393 & 0.015 & 0 & 0.505 & 0.051 & 0.010 & 0 & 0.020 & 0.005 & 196 \\
\hline \multicolumn{12}{|l|}{ Locus BST2.33 } \\
\hline Allele no. & 1 & 2 & 3 & 4 & 5 & 6 & 7 & 8 & 9 & & \\
\hline Allele size (bp) & 179 & 181 & 183 & 191 & 193 & 195 & 197 & 199 & 201 & & \\
\hline SQ & 0 & 0.049 & 0 & 0 & 0 & 0.303 & 0.500 & 0.139 & 0.008 & & 122 \\
\hline NQ & 0 & 0.030 & 0.005 & 0 & 0 & 0.262 & 0.569 & 0.134 & 0 & & 202 \\
\hline GOC & 0 & 0.016 & 0 & 0 & 0 & 0.291 & 0.505 & 0.181 & 0.005 & & 182 \\
\hline WA & 0.006 & 0.044 & 0.006 & 0.039 & 0.033 & 0.261 & 0.472 & 0.139 & 0 & & 180 \\
\hline \multicolumn{12}{|l|}{ Locus BST6.39TG } \\
\hline Allele no. & 1 & 2 & 3 & 4 & 5 & 6 & 7 & 8 & & & \\
\hline Allele size (bp) & 143 & 145 & 147 & 149 & 151 & 153 & 155 & 157 & & & \\
\hline SQ & 0.128 & 0.144 & 0.032 & 0.088 & 0.080 & 0.072 & 0.024 & 0.024 & & & \\
\hline NQ & 0.136 & 0.119 & 0.045 & 0.102 & 0.085 & 0.085 & 0.068 & 0.040 & & & \\
\hline GOC & 0.080 & 0.080 & 0.017 & 0.109 & 0.132 & 0.080 & 0.040 & 0.040 & & & \\
\hline WA & 0.139 & 0.117 & 0.028 & 0.111 & 0.117 & 0.072 & 0.061 & 0.022 & & & \\
\hline Allele no. & 9 & 10 & 11 & 12 & 13 & 14 & 15 & 16 & & & \\
\hline Allele size (bp) & 159 & 161 & 163 & 165 & 167 & 169 & 175 & 177 & & & \\
\hline SQ & 0.008 & 0.032 & 0.032 & 0.008 & 0.016 & 0.008 & 0.040 & 0.008 & & & \\
\hline NQ & 0.040 & 0.023 & 0.040 & 0.028 & 0.011 & 0.028 & 0.017 & 0.023 & & & \\
\hline GOC & 0.052 & 0.040 & 0.023 & 0.023 & 0.040 & 0.029 & 0.006 & 0.023 & & & \\
\hline WA & 0.006 & 0.039 & 0.033 & 0.028 & 0.022 & 0.017 & 0.033 & 0.022 & & & \\
\hline Allele no. & 17 & 18 & 19 & 20 & 21 & 22 & 23 & 24 & & & \\
\hline Allele size (bp) & 179 & 189 & 191 & 193 & 666 & 777 & 888 & 999 & & & \\
\hline SQ & 0.040 & 0.016 & 0.008 & 0.008 & 0.016 & 0.040 & 0.040 & 0.088 & & & 126 \\
\hline NQ & 0.040 & 0.023 & 0.006 & 0 & 0.011 & 0.006 & 0.011 & 0.011 & & & 176 \\
\hline GOC & 0.040 & 0 & 0 & 0 & 0.057 & 0.023 & 0.057 & 0.006 & & & 174 \\
\hline WA & 0.022 & 0.017 & 0.011 & 0 & 0.022 & 0.022 & 0.017 & 0.022 & & & 180 \\
\hline
\end{tabular}

populations, and a convincing explanation for the phenomenon has yet to be proposed. [Lessios (1992) summarizes the principles involved, while Bagley et al. (1999) discuss its relevance to microsatellite loci.]

Locus-by-locus exact tests of allelic frequencies revealed some significant differences between populations against a background of general allele-frequency homogeneity. Allele frequencies for locus BST2.33 for the WA sample were significantly different from those of GOC and NQ, but not from the SQ sample. For locus BST6.39TG, the GOC sample was significantly different from the SQ, but not from the WA or NQ sample (Table 4). From the AMOVA of the microsatellite data, a small $(0.17 \%)$ but significant $(P \approx 0)$ proportion of overall variance among the four populations was due to variation
Table 4. Microsatellite loci (above diagonal) that show significant (Bonferroni-corrected) allele frequency variation between pairs of mangrove jack populations

The populations are SQ, NQ, GOC and WA

\begin{tabular}{|c|c|c|c|}
\hline Population & NQ & GOC & WA \\
\hline SQ & None & $\begin{array}{c}\text { BST6.39TG } \\
(P=0.0067)\end{array}$ & None \\
\hline NQ & - & None & $\begin{array}{c}\text { BST2.33 } \\
(P=0.0036)\end{array}$ \\
\hline GOC & & - & $\begin{array}{c}\text { BST2.33 } \\
(P=0.0017)\end{array}$ \\
\hline WA & & & - \\
\hline
\end{tabular}


Table 5. Within-population nucleotide diversity (Kimura's two-parameter) for the $5^{\prime}$ end of the control region s.d., standard deviation

\begin{tabular}{lc}
\hline Population & Mean \pm s.d. \\
\hline SQ & $0.0616 \pm 0.0284$ \\
NQ & $0.0477 \pm 0.0265$ \\
GOC & $0.0754 \pm 0.0295$ \\
WA & $0.0610 \pm 0.0108$ \\
Bali & $0.0717 \pm 0.0181$ \\
Java & 0.0573 \\
Sumatra & $0.0903 \pm 0.0101$ \\
Samoa & $0.0591 \pm 0.0511$ \\
\hline
\end{tabular}

between populations $\left(F_{\mathrm{ST}}=0.0017\right)$. A likely biogeographic barrier (Torres Strait) was used to group the populations into Queensland east-coast samples (SQ, NQ) and northern Australian samples (GOC, WA). The amount of overall variation that was attributed to the difference between these two regional groups following AMOVA was small, but significant $\left(F_{\mathrm{CT}}=0.0008, P \approx 0\right)$.

\section{Mitochondrial DNA}

In $375 \mathrm{bp}$ at the $5^{\prime}$ end of the control region (GenBank accession no. AY166828), 108 variable sites were observed, including seven single-bp indels and one 5-bp indel across the sequences from 34 mangrove jacks. There were 33 haplotypes, one of which was represented by two fish. Controlregion sequence divergence within populations was about 4-7\% for the Australian sampling locations (Table 5). NonAustralian sampling locations were similar. Note that these diversity values are biased downwards as PAUP excludes indels during 'distance' analyses.

Of the 108 polymorphic nucleotide positions in the control region, 67 were parsimony informative (present in two or more fish). There were 255 MPTs that were 218 character state changes long. The topology of the strict consensus tree (Fig. 2) did not support the separation of Australian mangrove jack populations into a Queensland east-coast group and a northern and western Australian group. There was also no support for a genetic distinction between Australian and IndoPacific mangrove jack; for example, there were few clades (closely related groups) consisting only of Indonesian fish, or of Australian fish. Furthermore, the three Samoan fish appeared to be as related to fish from Australia as they were to fish from Indonesia and were not members of a unique or distantly related clade.

As expected, sequence variation in the ATPase 6 region was less extensive than the control-region sequences. In $415 \mathrm{bp}$ (GenBank accession no. AY166827), only 17 variable characters were observed among 56 fish; there were no indels. Five haplotypes were represented by more than one fish (Table 6) and eight fish had unique sequences. Haplotypes 1-5 represented fish from one or more population samples. Among the
17 polymorphic characters, only two were parsimony informative, leading to a single MPT with no homoplasy (Fig. 3). A pattern of genetic distinctiveness was not apparent among the population samples from the ATPase phylogenetic tree.

\section{Discussion \\ Population genetic structure}

From a genetic perspective, mangrove jack from different geographic areas in Queensland and Western Australia appear to be highly interconnected. Estimates of $F_{\mathrm{ST}}$ (microsatellites) were small (0.002) and the topological structure of MPTs from mtDNA sequence data showed no congruence with relationships between geographic areas. A high degree of interconnectedness on such a large scale is not without precedent. Ovenden et al. (1992) surveyed mtDNA sequence variation in populations of red rock lobster (Jasus edwardsii) over several thousand kilometres of southern Australian coastline, including Tasmania, and reported an apparent lack of subdivision that was accounted for by extensive dispersal during their long larval phase. The tailor (bluefish, Pomatomus saltatrix) has a life history more similar to that of mangrove jack. It spawns offshore but juveniles and subadults are commonly found in estuaries. Graves et al. (1992) analysed mtDNA in more than 400 North American tailor from populations along about $1000 \mathrm{~km}$ of mid-Atlantic coastline (North Carolina, Virginia and New Jersey) but reported no significant genetic differentiation. In Australia, Nurthen et al. (1992) found no evidence for stock structure among nine allozyme loci in tailor samples from the east coast. They did, however, find significant differences between samples from the western and eastern extremes of their distribution around the southern coastline of Australia. Jackass morwong (Nemadactylus macropterus) are distributed in the south from Brisbane in the east to Perth in the west, including Tasmania. The adults are demersal, living at $40-400 \mathrm{~m}$, whereas the juveniles are found on shallow reefs in Bass Strait and around Tasmania (Kailola et al. 1993). Both allozyme (Elliott and Ward 1994) and mtDNA (Grewe et al. 1994) analyses concluded that there was a lack of genetic differentiation among populations sampled throughout the range of the species in Australia, although there was significant, albeit minor, evidence of a genetically distinct population in New Zealand. As with other species with little or no genetic subdivision, the implication for mangrove jack populations is that they are connected through gene flow mediated by dispersal.

The minor microsatellite differences and lack of any mtDNA differences between tropical eastern and western Australia reported here shows the high level of gene flow experienced by mangrove jack populations. The Torres Strait region, in particular, is a major biogeographic boundary between the Pacific and Indian oceans over which many marine species are genetically subdivided. During the 
(a)

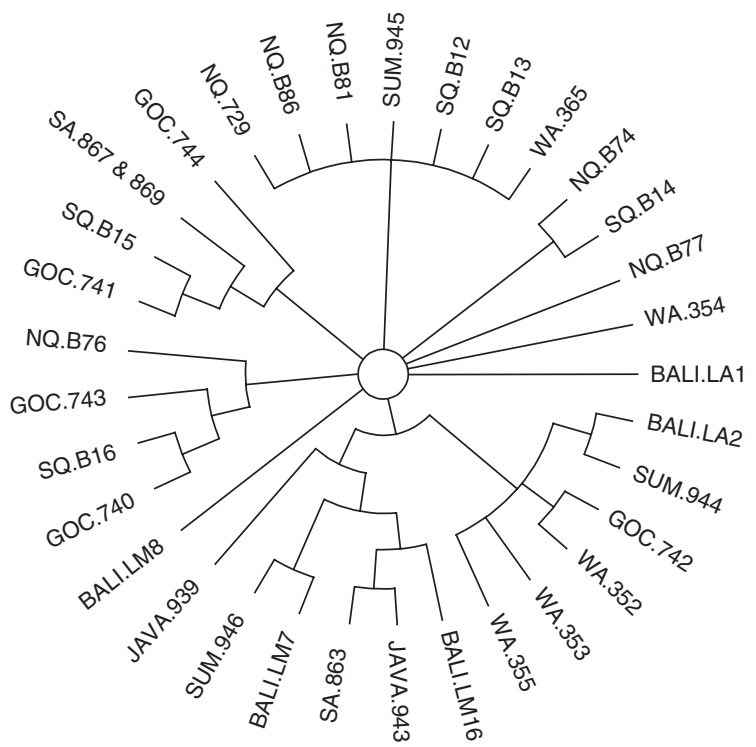

(b)
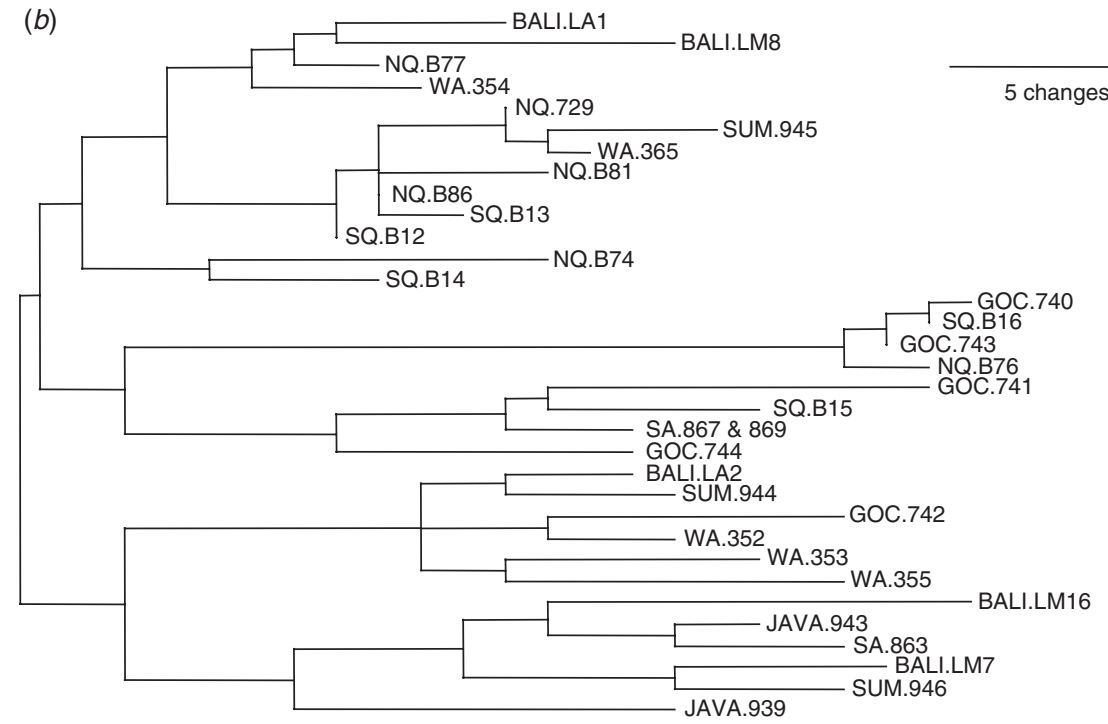

Fig. 2. Strict consensus tree of $255 \mathrm{MPTs}(a)$ and one mid-point rooted maximum parsimony phylogram of 255 trees $(b)$, constructed from control-region sequence data. The populations were SQ, NQ, GOC, WA, Bali, Java, Sumatra (SUM) and Samoa (SA).

Table 6. Numbers of identical ATPase sequences among six mangrove jack haplotypes, and the population from which the fish was collected

\begin{tabular}{llccrr}
\hline Population & \multicolumn{5}{c}{ Haplotype } \\
& 1 & 2 & 3 & 4 & 5 \\
\hline SQ & 5 & & & 4 & 1 \\
NQ & 9 & & & 1 & \\
GOC & 7 & 1 & & & \\
WA & 6 & 1 & & 1 & \\
Bali & 2 & 1 & 1 & 1 & \\
Java & 1 & & & 1 & \\
Sumatra & 2 & & 1 & 1 & 1 \\
Samoa & & & & 1 & \\
\hline
\end{tabular}

Pleistocene, the wide continental shelf to Australia's north including the Torres Strait was exposed, making Papua New Guinea and Australia a single land mass (van Oosterzee 1997). This vicariant event is reflected in the population genetics of at least three tropical Australian fishes - the saddle-tail sea perch (Lutjanus malabaricus) (Elliott 1996); barramundi (Chenoweth et al. 1998b) and Spanish mackerel (J. R. Ovenden, R. Street, R. C. Buckworth, C. Foschia and S. J. Newman, unpublished data) - and of green turtles (Norman et al. 1994). The frequencies of the three most common RFLP (restriction fragment length polymorphism) haplotypes in sea perch mtDNA were 61,15 and $12 \%$ in a sample from the Queensland east coast (near Townsville), 


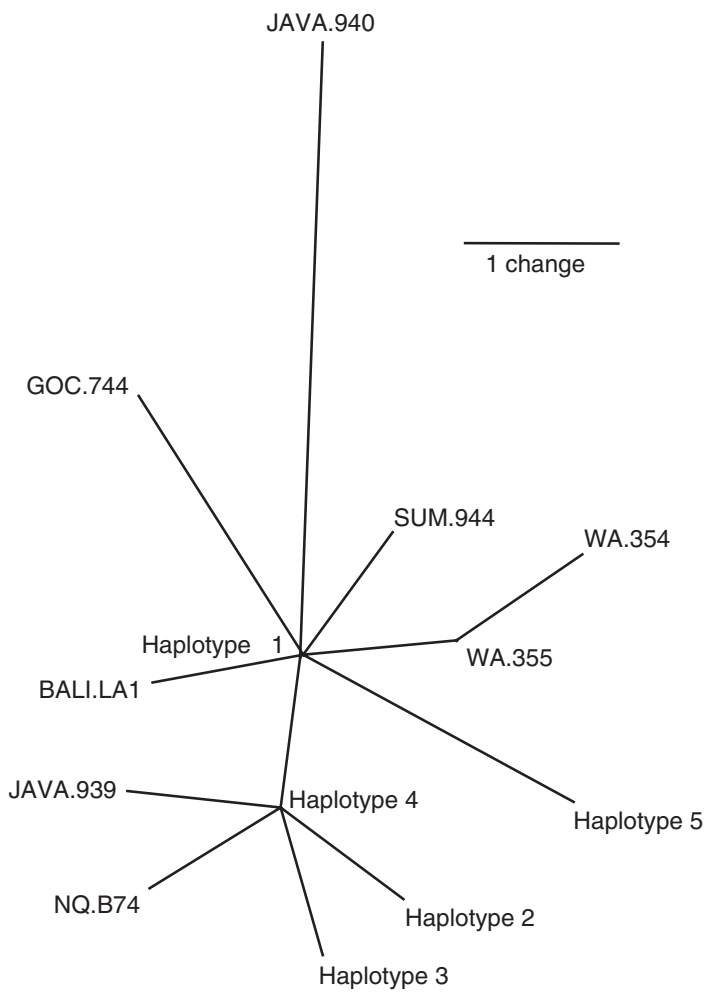

Fig. 3. Unrooted maximum parsimony tree constructed from ATPase sequence data. Each branch represents a fish or group of identical fish grouped into haplotypes (Table 6). Fish were sampled from the following populations: SQ, NQ, GOC, WA, Bali, Java, Sumatra (SUM) and Samoa.

but were 27, 26 and $29 \%$ in samples taken from the Gulf of Carpentaria and north-west Western Australia. Chenoweth et al. (1998a) reported a net mtDNA sequence divergence of $4 \%$ (control region) and $0.47 \%$ (ATPase region) between barramundi populations sampled to the east and west of Torres Strait. For Spanish mackerel, an mtDNA RFLP marker was found in $20-25 \%$ of the fish sampled from the Queensland east coast (near Townsville), but in only 2\% of the fish sampled from the Gulf of Carpentaria (J. R. Ovenden, R. Street, R. C. Buckworth, C. Foschia and S. J. Newman, unpublished data). Similarly, Norman et al. (1994) reported mtDNA clades that were endemic to green turtle rookeries from either the Pacific Ocean or the Indian Ocean and Gulf of Carpentaria. The absence of mtDNA sequence differences between Queensland and GOC/WA mangrove jacks shows the high vagility of the species despite the presence of a major biogeographic boundary. Large long-shore movements by larvae or adults have presumably erased any impact made by the successive formation of a land bridge between northern Australia and New Guinea on the pattern of population subdivision in this species. Mark-recapture data for adult mangrove jack have revealed that some individuals are capable of moving several hundred kilometres from coastal habitats to offshore reefs (J. Russell, unpublished data).
Evidence from mtDNA sequence data reported here suggests that the vagility of mangrove jack is also high enough to effectively homogenize populations in Australia and near South-East Asian countries. This is in contrast to a recent study where a genetic break was demonstrated between northern Australian and Indonesian populations of snapper. Ovenden et al. (2002) reported that $14 \%$ of the total molecular variance among restriction-site mtDNA haplotypes for the goldband snapper (Pristopomoides multidens) was attributable to genetic distinction between South-East Asian and Australian samples. Indonesian (Kupang, West Timor) and Australian (Kimberley) sampling locales had significantly different haplotype frequencies (haplotype AACAA: Kupang, 0.018; Kimberley, 0.180; BACBA: Kupang, 0.018; Kimberley, 0.120; and BBCBA: Kupang, 0.333; Kimberley, 0.075) despite geographic separation over only $300-400 \mathrm{~km}$. Although mtDNA has proven an excellent marker in other species to detect genetic subdivision between northern Australian and South-East Asian populations, no similar pattern is evident for mangrove jack. It would be worthwhile to validate the apparent high level of gene flow across national boundaries in mangrove jack with further genetic markers, such as microsatellites.

In population genetics, two models account for the generation of new, mutant alleles: the infinite allele model (IAM) and stepwise mutation model (SMM). Assuming equilibrium between mutation and genetic drift has been achieved in a population, the models can be used to estimate expected heterozygosity and gene flow $\left(N_{\mathrm{m}}\right)$ and to partition genetic variance within and between populations (Nei and Kumar 2000). The $F_{\mathrm{ST}}$ values presented herein to partition microsatellite genetic variance assume the IAM; the SMM equivalent $\left(R_{\mathrm{ST}}\right)$ has not been presented. It is unclear which model is the most appropriate for microsatellite data, and several authors regard the solution to lie between the extremes of IAM and SMM (Bagley et al. 1999; Nei and Kumar 2000). Several recent applications of microsatellites to spatial differentiation in fisheries species have reported similar results with $F_{\mathrm{ST}}$ and $R_{\mathrm{ST}}$ (Ruzzante et al. 1996; Smith and McVeagh 2000). Given the concordance between mtDNA and microsatellite results reported here for mangrove jack, it is unlikely that the implementation of $R_{\mathrm{ST}}$ would uncover hidden population subdivision.

\section{Implementation of microsatellite loci in non-target species}

Instead of developing microsatellite loci in this study that were unique to mangrove jack, we took advantage of the ability of some loci to cross species boundaries. Di-, tri- and tetranucleotide perfect and complex repeat loci (van Herwerden et al. 2000a) for coral trout and red-throat emperor were discarded if (1) PCR product was absent or smeared, (2) the locus was monomorphic, (3) allele frequencies were out of Hardy-Weinberg equilibrium, or (4) more than two bands were observed per individual. Although only $11 \%$ (4 of 44 ) of 
loci met these criteria, the screening process was judged to be more cost and time efficient than developing, sequencing and optimizing a new and specific set of loci for mangrove jack. Our allele size ranges largely agreed with that reported previously (van Herwerden et al. 2000a): 90RTE, 190 bp in redthroat emperor and 175-199 bp in mangrove jack; BST6.56, 121 and 129-151 bp respectively; BST2.33, 230 and 179-201 bp respectively; BST6.39TG, 133 and 143-193 bp respectively. We did not confirm the nature of the repeat in mangrove jack by direct sequencing. Interestingly, three of the four loci selected for this study were independently found to amplify in a range of serranid, lethrinid, lutjanid and labrid species (BST2.33 and 90RTE; van Herwerden et al. 2000b) and in Spanish mackerel (90RTE and BST6.39TG; D. P. Broderick and J. R. Ovenden, unpublished data).

\section{Adaptive population divergence}

Adaptive population divergence is the evolutionary response of a population to its environment. Its magnitude depends on the heritability of the adaptive trait and the strength of the selective pressure exerted on the trait by the environment. Adaptive traits, unlike molecular markers (traits) are rarely controlled by a single genetic locus or exhibit discrete phenotypes, and are subject to complex interactions such as dominance, epistasis and pleiotropy. Yet these traits make up the genetic architecture that confers on populations the unique characteristics that are perceived to be worthy of conservation. A recent meta-analysis (Reed and Frankham 2001) has contributed to the controversy surrounding the extent to which variation in neutral molecular markers is positively correlated with variation in adaptive traits. Among 71 data sets, they found the correlation to be weak and concluded that the molecular measures of genetic diversity had only a limited ability to predict diversity in adaptive traits. Molecular markers are used extensively in conservation biology to rapidly, cheaply and non-invasively measure genetic divergence, but the study of Reed and Frankham (2001) raises concerns over whether they should be used in isolation to define evolutionarily significant units (ESUs; Moritz 1994) that may be worthy of special conservation status.

ESUs and their evolutionary potential are preserved in an effort to halt, and possibly recreate, lost biodiversity assuming evolutionary processes continue to operate. Despite their lack of correlation with adaptive traits, molecular markers have been successful in the identification of ESUs, when as much ecological information as possible is included in the definition of the ESU (McKay and Latta 2002). It is the use of molecular markers for more short-term actions, such as intentional translocations for economic or social benefit, where the addition of ecological data is not only desirable but also essential. At this scale, ecological and climatic gradients become as relevant for assessing differentiation in population adaptive divergence as molecular markers (McKay and Latta 2002). Precise matching between donor and recipient populations for presumed adaptive characteristics is an important precursor for success.

This study was conducted to define the molecular boundaries of ESUs for mangrove jack in Queensland. Unless distinct ecological subunits are discovered within the range of mangrove jack in Queensland, the definition of an ESU for this species includes the entire Queensland population. However, no latitudinal gradients in abundance were reported for mangrove jack in seven streams along $320 \mathrm{~km}$ of northern Queensland coastline (J. Russell, unpublished data). In circumstances where intentional translocations were intended to establish or supplement populations, more-precise ecological matching between donor and recipient populations is recommended.

We regard Queensland populations of mangrove jack as belonging to a single ESU. However, the addition of ecological information to the definition of the Queensland mangrove jack ESU is desirable, particularly in light of the large ecological gradient experienced by the species in Queensland. Translocations for establishing new populations in landlocked freshwater impoundments in Queensland are unlikely to adversely affect the population genetic structure of the species. We recommend the use of locally derived broodstock, where possible, to achieve maximum stocking success and to minimize potential disruption to locally adapted subpopulations. Translocations for the purposes of restoring populations adversely affected by environmental change or anthropogenic effects should not occur until the molecular marker information is augmented with fine-scale ecological data to test for correlations between physical features of the environment and biological characteristics.

\section{Acknowledgments}

Lynne van Herwerden and John Benzie assisted in the use of microsatellite loci from blue-spot trout and red-throat emperor. We thank Kelly Ewen-White and her team (AGRF) for efficiently and accurately producing the microsatellite genotyping data. Keely Moran ably assisted with proofreading of the data. The mangrove jack team of the Queensland Department of Primary Industries Northern Fisheries Centre (John Russell, Andew McDougall and Adam Fletcher) collected and organized fin clips. Several recreational and commercial fishers cooperated to provide the fin clips and we are grateful to them all. In particular we thank Arnil C. Emata (South-East Asian Fisheries Development Centre, Aquaculture Department, Tigbauan, Iloilo, Philippines), Haryanti (Research Institute for Mariculture, Gondol, Bali, Indonesia) and Kelvin Passfield (Samoa Fisheries Project, Fisheries Division, Apia, Samoa). Comments from Michael Hutchison, Andy Moore, John Russell and two anonymous reviewers improved the quality of the manuscript. World coastline data are reproduced with the permission of Geoscience Australia 2001. 


\section{References}

Allen, G. R., Midgley, S. H., and Allen, M. (2002). 'Field Guide to the Freshwater Fishes of Australia.' (CSIRO Publishing: Melbourne.)

Allendorf, F. W., Leary, R. F., Spruell, P., and Wenburg, J. K. (2001). The problems with hybrids: setting conservation guidelines. Trends in Ecology and Evolution 16, 613-22.

Anonymous (1999). Overview of fisheries (freshwater) management plan. Queensland Fisheries Management Authority, Department of Primary Industries, Brisbane.

Anonymous (2000). 'Sequencher.' (Gene Codes Corporation: Ann Arbor, Michigan.)

Ayvazian, S. G., Johnson, M. S., and McGlashan, D. J. (1994). High levels of genetic subdivision of marine and estuarine populations of the estuarine catfish Cnidoglanis macrocephalus (Plotosidae) in southwestern Australia. Marine Biology 118, 25-31.

Bagley, M. J., Lindquist, D. G., and Geller, J. B. (1999). Microsatellite variation, effective population size, and population genetic structure in the vermilion snapper, Rhomboplites aurorubens, off the southeastern USA. Marine Biology 134, 609-20.

Bartley, D. M., Kent, D. B., and Drawbridge, M. A. (1995). Conservation of genetic diversity in a white seabass hatchery enhancement program in southern California. In 'Uses and Effects of Cultured Fishes in Aquatic Ecosystems'. (Eds H. L. Schramm and R. G. Piper.) pp. 249-58. (American Fisheries Society: Bethesda, Maryland.)

Begg, G., Keenan, C., and Sellin, M. (1998). Genetic variation and stock structure of school mackerel and spotted mackerel in northern Australian waters. Journal of Fish Biology 53, 543-59.

Buonaccorsi, V. P., McDowell, J. R., and Graves, J. E. (2001). Reconciling patterns of inter-ocean molecular variance from four classes of molecular markers in blue marlin (Makaira nigricans). Molecular Ecology 10, 1179-96.

Chenoweth, S. F., Hughes, J. M., Keenan, C. P., and Lavery, S. (1998a). When oceans meet: a teleost shows secondary intergradation at an Indian-Pacific interface. Proceedings of the Royal Society of London, Series B 265, 415-20.

Chenoweth, S. F., Hughes, J. M., Keenan, C. P., and Lavery, S. (1998b). Concordance between dispersal and mitochondrial gene flow: isolation by distance in a tropical teleost, Lates calcarifer. Heredity 80, 187-97.

Doherty, P., and Fowler, T. (1994). An empirical test of recruitment limitation in a coral reef fish. Science 263, 935-9.

Doi, M., and Singhagraiwan, T. (1993). 'Biology and Culture of the Red Snapper, Lutjanus argentimaculatus.' (The Eastern Marine Fisheries Development Center: Thailand.)

Elliott, N. (1996). Allozyme and mitochondrial DNA analysis of the tropical saddle-tail sea perch, Lutjanus malabaricus (Schneider), from Australian waters. Marine and Freshwater Research 47, 869-76.

Elliott, N., and Ward, R. (1994). Enzyme variation in jackass morwong, Nemadactylus macropterus (Schneider, 1801) (Teleostei: Cheilodactylidae), from Australian and New Zealand waters. Australian Journal of Marine and Freshwater Research 45, 51-67.

Excoffier, L., Smouse, P. E., and Quattro, J. M. (1992). Analysis of molecular variance inferred from metric distances among DNA haplotypes: application to human mitochondrial DNA restriction data. Genetics 131, 479-91.

Fitzsimmons, N. N., Moritz, C., Limpus, C. J., Pope, L., and Prince, R. (1997). Geographic structure of mitochondrial and nuclear gene polymorphisms in Australian green turtle populations and malebiased gene flow. Genetics 147, 1843-54.

Garrett, R. N. (1994). Hatchery breeding of mangrove jack Lutjanus argentimaculatus and barramundi Lates calcarifer. In 'Abstracts from Australian Barramundi Farming Workshop', Cairns, Australia,
17 August 1994. (Department of Primary Industries: Brisbane, Australia.) (Abstract.)

Graves, J., McDowell, J., Beardsley, A., and Scoles, D. (1992). Stock structure of the bluefish Pomatomus saltatrix along the mid-Atlantic coast. Fishery Bulletin 90, 703-10.

Grewe, P. M., Smolenski, A. J., and Ward, R. D. (1994). Mitochondrial DNA diversity in Jackass Morwong (Nemadactylus macropterus: Teleostei) from Australian and New Zealand waters. Canadian Journal of Fisheries and Aquatic Science 51, 1101-9.

Johnson, M. S., Creagh, M., and Moran, S. (1986). Genetic subdivision of stocks of snapper Chrysophrys unicolor in Shark Bay, Western Australia. Australian Journal of Marine and Freshwater Research 37, 337-45.

Kailola, P. J., Williams, M. J., Stewart, P. C., Reichelt, R. E., McNee, A., and Grieve, C. (1993). 'Australian Fisheries Resources.' (Bureau of Resource Sciences: Canberra.)

Keenan, C. P. (1994). Recent evolution of population structure in Australian barramundi, Lates calcarifer (Bloch): an example of isolation by distance in one dimension. Australian Journal of Marine and Freshwater Research 45, 1123-48.

Keenan, C. P. (1998). Should we allow human-induced migration of the Indo-West Pacific fish, barramundi Lates calcarifer (Bloch) within Australia? Aquaculture Research 29, 1-11.

Kimura, M. (1980). A simple method for estimating evolutionary rates of base substitutions through comparative studies of nucleotide sequences. Journal of Molecular Evolution 16, 111-20.

Lessios, H. A. (1992). Testing electrophoretic data for agreement with Hardy-Weinberg expectations. Marine Biology 112, 517-23.

Maddison, W., and Maddison, D. (1992). 'MacClade.' (Sinauer: Sunderland, Massachusetts.)

McKay, J. K., and Latta, R. G. (2002). Adaptive population divergence: markers, QTL and traits. Trends in Ecology and Evolution 17, 285-91.

Morgan, E. (2000). 'Genepop on the Web.' http://wbiomed.curtin.edu. au/genepop (Curtin University of Technology: Perth.)

Moritz, C. (1994). Defining evolutionarily significant units for conservation. Trends in Ecology and Evolution 9, 373-5.

Nei, M., and Kumar, S. (2000). 'Molecular Evolution and Phylogenetics.' (Oxford University Press: Oxford.)

Norman, J. A., Moritz, C., and Limpus, C. J. (1994). Mitochondrial DNA control region polymorphisms: genetic markers for ecological studies of marine turtles. Molecular Ecology 3, 363-73.

Nurthen, R., Cameron, R., and Briscoe, D. (1992). Population genetics of tailor, Pomatomus saltatrix (Linnaeus) (Pisces: Pomatomidae) in Australia. Australian Journal of Marine and Freshwater Research 43, 1481-6.

Ovenden, J. R. (1990). Mitochondrial DNA and marine stock assessment: a review. Australian Journal of Marine and Freshwater Research 41, 835-53.

Ovenden, J. R., Brasher, D. J., and White, R. W. G. (1992). Mitochondrial DNA analyses of the red rock lobster Jasus edwardsii supports an apparent absence of population subdivision throughout Australasia. Marine Biology 112, 319-26.

Ovenden, J. R., Lloyd, J., Newman, S. J., Keenan, C. P., and Slater, L. S. (2002). Spatial genetic subdivision between northern Australian and southeast Asian populations of Pristipomoides multidens: a tropical marine reef fish species. Fisheries Research 59, 57-69.

Raymond, M., and Rousset, F. (1995). GENEPOP (version 1.2): population genetics software for exact tests and ecumenicism. Journal of Heredity 86, 248-9.

Reed, D. H., and Frankham, R. (2001). How closely correlated are molecular and quantitative measures of genetic variation? A meta-analysis. Evolution 55, 1095-103. 
Rice, W. R. (1989). Analysing tables of statistical tests. Evolution $\mathbf{4 3}$ 223-5.

Ruzzante, D. E., Taggart, C. T., and Cook, D. (1996). Spatial and temporal variation in the genetic composition of larval cod: cohort contribution and genetic stability. Canadian Journal of Fisheries and Aquatic Sciences 53, 2695-705.

Schneider, S., Kueffer, J. M., Roessli, D., and Excoffier, L. (2000). 'Arlequin: A Software for Population Genetic Data Analysis.' (Genetics and Biometry Lab, Department of Anthropology, University of Geneva: Geneva.)

Shaklee, J. B. (1983). The utilization of isozymes as gene markers in fisheries management and conservation. In 'Isozymes. Current Topics in Biological and Medical Research. Vol. 11'. (Eds M. Rattazzi, J. G. Scandalios and G. S. Whitt.) pp. 213-47. (Alan R. Liss: New York.)

Shaklee, J. B., and Bentzen, P. (1998). Genetic identification of stocks of marine fish and shellfish. Bulletin of Marine Science 62, 589-621.

Skibinksi, D. O. F. (1997). Genetical aspects of fisheries enhancement. In 'FAO/DFD Expert Consultation on Inland Fisheries Enhancements' (Ed. T. Petr.) pp. 205-22. (FAO: Dhaka.)

Smith, P., and McVeagh, M. (2000). Allozyme and microsatellite DNA markers of toothfish population structure in the southern ocean. Journal of Fish Biology, Supplement A 57, 72-83.
Swofford, D. L. (1999). 'PAUP*: Phylogenetic Analysis Using Parsimony.' (Sinauer: Champaign, Illinois.)

van Herwerden, L., Benzie, J., Peplow, L., and Davies, C. (2000a) Microsatellite markers for coral trout (Plectropomus laevis) and red throat emperor (Lethrinus miniatus). Technical Report No. 32, Australian Institute of Marine Science, Townsville.

van Herwerden, L., Benzie, J., Peplow, L., and Davies, C. (2000b) Microsatellite markers for coral trout (Plectropomus laevis) and red throat emperor (Lethrinus miniatus) and their utility in other species of reef fish. Molecular Ecology 9, 1919-52.

van Oosterzee, P. (1997). 'Where Worlds Collide: The Wallace Line.' (Reed Books: Melbourne.)

Ward, R. D., and Grewe, P. M. (1994). Appraisal of molecular genetic techniques in fisheries. Reviews in Fish Biology and Fisheries 4 300-25.

Yang, Z. (1996). Among-site rate variation and its impact on phylogenetic analyses. Trends in Ecology and Evolution 11, 367-72.

Manuscript received 28 October 2002; revised and accepted 13 February 2003. 